\title{
The Origins and Social Implications of COVID-19: The Need for a Critical Approach and Discussion from the Society
}

\author{
Norma González González \\ Faculty of Political and Social Sciences, Autonomous University of the State of Mexico (UAEMex), Toluca, Mexico State, Mexico.
}

How to cite this paper: Norma González González. (2021) The Origins and Social Implications of COVID-19: The Need for a Critical Approach and Discussion from the Society. International Journal of Clinical and Experimental Medicine Research, 5(4), 505-513.

DOI: 10.26855/ijcemr.2021.10.013

Received: September 8, 2021

Accepted: September 30, 2021

Published: October 29, 2021

*Corresponding author: Norma González González, Faculty of Political and Social Sciences, Autonomous University of the State of Mexico (UAEMex), Toluca, Mexico State, Mexico. Email: gogn@uaemex.mx

\begin{abstract}
As an essay, this document raises the need to address the issue of the pandemic that currently affects the global world, recovering central approaches for discussion and analysis that have been marginalized in the approach, discussion and knowledge about a health phenomenon that today more than ever, reveals the historical, social, economic and cultural character of health; its profound implications in terms of what is already seen as a watershed in the history of the modern world, and in this sense, those that are presupposed as profound transformations in coexistence and social interactions on a world scale. Hence, the need for an approach that strives to recover a phenomenon that beyond its deployment and medical intervention, requires to be seen from the complexity of its origins and socio-historical and political representations, for the sake of knowledge and decision-making tending to work on the causes that originate it.
\end{abstract}

\section{Keywords}

Sociology of health, Public health, Health and subjectivity, COVID-19 and society, Health Epistemology

\section{Introduction}

In this document, some central ideas about the urgency and importance of rethinking the historical-social origin of the health/disease/death process are rescued. In the field of social sciences, it is from sociology, anthropology and social psychology, where a vast and important theoretical and methodological work has been developed that provides the support for this approach [1-4]. Thus, the biomedical model, understood as the result of an epistemological construction that in the framework of modernity, makes the so-called scientific knowledge the central and key reference for the definition and care of what is socially and institutionally defined individually as the health-disease process, maintains a clear hegemony in research and scientific knowledge around health problems, in such a way that governments and society in general deposit in biomedical research and its related fields, the approach and the solution to what ails us in sanitary terms [5].

The complex situation that we are going through today makes the COVID-19 phenomenon a clear reference to what is proposed here, prioritizing medical knowledge, to the detriment of a broader and deeper discussion that has elements to rethink the disease as a product of the conditions and the type of relationships inherent to a social organization [6] from which enormous inequalities and social inequalities result, which translate into poverty and marginalization for broad sectors of the population in the different regions and countries of the world. In addition, with increasing force, approaches are being recovered that in the predation and excessive exploitation of nature, see 
particular and irrational forms of relationship and coexistence with the environmental environment $[7,8]$, a fertile land for the emergence and the spread of the so-called "new infectious diseases", and their specific weight in the framework of a globalized, interconnected and interdependent world, with the implications that this implies in terms of control, monitoring and regulation of a health crisis of the dimensions that we now experience.

\section{Health disease as a historical/social construction}

The moment we are currently going through urges the need to reflect and act around health procurement and care, not only or exclusively from the field of biomedicine, but also and perhaps more importantly, from that other plane that represents the social, and that historically has been relegated in the face of the advancement of biomedical and diagnostic technologies, linked to fields such as chemistry, biology, the so-called neurosciences, physics itself, among the most prominent and representative [9-11]. Hence, the central concern of this text is to contribute to rethinking the so-called health problem, from a historical and social perspective and approach, undoubtedly of an economic and cultural nature.

As mentioned at the beginning of this document, the fact that in the different contexts where the pandemic is lived and takes place: at the global, regional, national, local level, is powerfully striking hopes are focused on having a vaccine that can scare away and rid us of the fears unleashed by covid-19. Fear of getting infected, fear of dying, or that the virus will attack our loved ones. In the scenario of the global village, the collective imagination locates the possible solution in a place alien to the social and institutional responsibilities from where the material and ideological conditions originate that make the definition and, to that extent, the existence of the agents possible pathogens (in this case viruses), and their chances of causing harm to a population; reaching dimensions such that they have exposed another great fear: there is no place within the limits of today's world where one can escape the pandemic. The pandemic occurs in a common place and space, in real time; product of that transformation started at the end of the last century, known as globalization, and which in real time has reduced the limits of the world, standardizing the production and consumption of goods and services, but also the risks, fears and borders of our fears [12-14].

COVID-19 formally represents a new health phenomenon of different dimensions, the WHO defines a pandemic in terms of “... the worldwide spread of a new disease" [15], this definition is interesting because already in 2009, and in the face of the H1N1 virus, from the perspective of international health organizations, it was necessary to clear the way towards a clearer definition of this type of global phenomenon that, it is noted, will accompany us in the years to come.

With regard to their mutability, for human beings, viruses represent a challenge to scientific knowledge and the mechanisms to face them in terms of knowledge, biomedical technologies and related areas capable of slowing down their development and spread (as far as is known today: the development of antivirals and vaccines). Unlike what seems to have been achieved in the case of bacteria, with a better known behavior and in that sense more predictable in the way of a scientific approach for its possible control. However, according to an epidemiological approach that places the disease in the context of its historicity and social condition [16, 17], both viruses and bacteria or any other pathogenic agent require environments conducive to its spread and contagion in a host (social hosts) whose degree of vulnerability will depend in turn on the conditions of strength or vulnerability in which what is known as the immune system is found, that is, the response capacity of the human body to face both external and internal aggressions, and of different biological nature, chemical physics, etc. This tour is necessary and useful to illustrate that by itself a virus or a bacterium is not synonymous with disease, but rather requires given and socially produced conditions to achieve its morbidity and lethality capacity [18-20]. The triad: virus, host and environment, shapes and gives meaning to the presence and development of diseases, basically infectious in nature [21, 22].

Historical and epidemiological investigations have revealed the way in which the improvement of socioeconomic conditions and the incorporation of hygiene measures have been a fundamental pillar in the modern world fight against diseases and the improvement of diseases health conditions of populations; a position that introduces a crucial concept in the field of public health, that of populations, since this position deals with health in a collective sense, not with bodies at the individual level, but with the whole that represents the social body [23-25].

\section{Critical voices demanding a comprehensive vision of the pandemic}

Faced with the health crisis, we are currently experiencing, critical voices are raised, as in the case of the renowned and prestigious British magazine Lancet, where, in the voice of Horton, the need for a more comprehensive treatment of the pandemic is highlighted; not only prioritizing and focusing on the advances of 
possible vaccines (which undoubtedly maintains its own relevance) but jointly recovering the bio-health and social aspects that are a central part of this coronavirus problem [26]. The magazine emphasizes the fact that social inequalities are not being sufficiently addressed, and in this sense the term is recovered: syndemia, proposed in the 90s to clarify and express that the confluence of diseases and social factors aggravate the effects of a pathology such as covid-19. Thus, on the one hand, we have the SARS CoV2 virus that causes COVID-19, and on the other hand, the group of non-contagious pathologies that, according to what has been declared since the beginning of the pandemic, complicate the course of the disease: hypertension, obesity, cancer, diabetes, brain and cardiovascular diseases, and to which are added the conditions of social inequality [27, 28].

Along this same critical line, newspapers such as El País in Spain or La Jornada in Mexico have echoed, recovering the voices of intellectuals who at an international level, as well as professionals in medicine and the social sciences, are concerned about approaching the phenomenon from a more comprehensive perspective, questioning whether it is possible to propose solutions to the pandemic regardless of the contribution of the view provided by the social sciences [29]. Similarly, intellectuals such as Zizek, Boaventura de Sousa, Chomsky, Agamben, among others, in a first approach and general reflection, recover the pandemic from its deep political, social and cultural implications [30-32].

\section{Health and poverty: Living conditions, health conditions}

The conditions of poverty and marginalization in which a large part of the world's population lives, invariably associated with precarious living conditions in terms of food, education, housing, access to health services, among the most prominent, represent favorable conditions for the development and spread of infectious diseases such as the one that concerns us now. Thus, those who participate in unsanitary environments will be more susceptible to contracting, developing and dying from an infectious disease; that is, those who survive on a daily basis in contexts of poverty and marginalization, with no or limited access to health care services, a reality for large sectors of the population in Mexico and in the world [33].

In his book From Medical Police to Social Medicine, Rosen mentions that insofar as disease is the result of, or affects, social conditions and relationships in which human beings live, it is a social phenomenon that must be known and studied as such [34]. The same World Health Organization WHO refers to the "Social Determinants of Health" as those circumstances in which people are born, grow up, live, work and age, and where the health system is included of course [35]. Along the same lines, the same body refers to the so-called circumstances, as a product of the distribution of money, power and resources at the global, national and local levels, and in turn depend on the forms of production and the policies adopted in the different spheres of life in society, particularly those that have to do with politics and social economic development. Thus, following this international organization in the health field, it is the social determinants of health, from which most of the health inequities are explained, that is, the unjust and avoidable differences observed in and between countries in what regarding the health situation [36].

The forms of social coexistence defined by productivist goals at the cost of the destruction and depletion of natural resources, overcrowding and deterioration of the conditions and quality of life in large cities, as well as desolation and the abandonment of spaces rural areas, has given way to what as a whole represents the landscape and the current expression of socio-economic inequalities and inequalities, where a social and economic distribution of illness and death makes sense [37].

In the particular case of Mexico, it is not fortuitous that in the capital city, deaths from COVID-19 are concentrated in some of the municipalities that are historically identified by their worrying poverty and marginalization rates, namely Iztapalapa and Gustavo A. Madero [38]. To the initial precept that we are all at risk of being infected with the virus, we must define those particular conditions that on a day-to-day basis end up defining the course of the possible contagion, its virulence and lethality: unhealthy living conditions that favor the contagion, a strengthened or compromised immune system that depends on the conditions of food, nutrition, a home with drinking water and drainage services, and of course on the availability and access to health services that, after all, already present or declared the disease can make the difference between life and death (at a certain moment have, for example, a respirator); which together implies a complex scenario with clear socio-economic, political and cultural connotations.

The first balance sheets made by educational and governmental institutions present a first balance of the impacts that the COVID-19 pandemic has had on the economy, trade, employment conditions, living conditions and the well-being of the population, in a country that, like Mexico, has been facing enormous social deficiencies derived from conditions of poverty and inequality; a problem that is now seriously multiplied and increased in the face of a 
problem of the global dimensions that we experience today [39, 40]. The intention of these works is to generate knowledge that can dimension the problems generated, and where appropriate be in a position to give way to strategies aimed at social protection and strategies in favor of a new management of the economy, to the light of a series of calls for attention that are beginning to be exposed in different national and international forums regarding the need and urgency of a more sustainable economy.

Likewise, it is highlighted that the consequences of the pandemic reveal an increase in extreme poverty that goes from $17 \%$ to $22 \%$ of the population, which is undoubtedly directly related to the employment conditions of people, which in In the context of the pandemic, they have been forced to accept increasingly precarious wages, facing the threat of losing their jobs. One more piece of information confirms the close relationship between living conditions and health "... the disaggregated analysis shows a totally different face of the pandemic in the city. When observing the historical active cases at the colony level, it is that some towns of low social development stratum such as San Bartolo Ameyalco (Álvaro Obregón), San Francisco Tlaltenco and San Pedro (both in Tláhuac), San Salvador Cuauhtenco (Milpa Alta), and Santa María Nativitas (Xochimilco), among other colonies, have been the ones with the highest number of accumulated cases between july and november of last year.” [41].

Phrases such as "Health for all by the year 2000" [42, 43], or more recently the "Millennium Development Goals" [44], show the urgency to return to a critical approach to knowledge and actions around health, based on the consideration of its origin and historical and social nature. Social and institutional interest and concern for health cannot be reduced and limited to decrees and official and media declarations, no matter how well intentioned they may be. While neither can health be held hostage to a type of scientific knowledge based on a hegemonic biomedical model, whose limits are now more than ever evident, calling into question its scope and limitations [45]. It is not a question, of course, of denying and ignoring the importance of biomedical knowledge, but rather of locating its scope and implications in terms of the search for health care, rather than care for the disease, promoting synergies that prevent the saturation of hospitals and the depletion of medical-pharmacological resources. Since the beginning of this century, national and international forums have emphasized the fact that there are no economic resources capable of meeting the growing demand for services and care, directed at health systems in different regions of the world [46], so it is necessary and urgent to change and reorient the model of care and attention to the health phenomenon, beyond what until today has privileged care focused on the sick subject and its approach from a medical perspective that more than health directs its attention to disease.

\section{Health and subjectivity: Tow ards new forms of relationship and social interaction}

It is worth remembering that historically, the subjective experience of the disease is marked by an important difference between diseases of an infectious type, and those called: chronic degenerative. Infections take place in a short time, in a matter of days a population can be decimated by infections; let us remember the history of the great epidemics that swept Europe in the past, the pain is lived under the cover of the surprise arrival of death, and the speed with which it occurs. In the case of diseases: chronic degenerative, the pain lasts over time, it may be years in which the patients and their family environment live that exhausting experience of the disease, marked by a series of symbolisms and sociocultural representations that stigmatize the chronically ill, separating them from what is recognized as a normal life. In both cases, there is present that foundation and social origin that defines and signifies the disease, as well as its corresponding therapeutic processes.

This sense, the COVID-19 pandemic, represents a radical change in the course of Western history. The dimensions of this historical break are still impossible to define but they cut across all areas, corners and interstices of human life. In the midst of uncertainty, a recomposition and reconfiguration of the ways in which we relate and make life in society possible is taking place [47]. It will be very difficult that in the short and medium term we can banish from our lives fear, fear, rejection of a virus installed in a collective imagination that fears contagion, and that in this route gives rise to myths that stigmatize so much those who they contract the virus like those who care for the disease/the sick [48]; those who have recovered from the disease are being rejected and find that their social environment is not prepared to receive them, to embrace and welcome their return. Likewise, especially at the beginning of the pandemic, in different countries and regions of the world, health personnel have suffered attacks as a result of the stigmatization of work that, far from being recognized and valued, was assumed as a source of contagion.

It is a brand that for the moment, and in different senses and directions, it is assumed, will accompany us throughout our lives, and perhaps it is already part of the next generations, which in addition to their own challenges have to face this anticipated inheritance [49]. From forums and international organizations, it is warned 
about the beginning of an era marked by the advent of new diseases, especially infectious ones, and before which we remain oblivious and on the sidelines both at a social and institutional level; the COVID-19, despite what it has meant in each and every one of the levels and areas of life in society, seems to have neither the power nor the strength to recover everything that has to do with health from a responsibility and social and institutional involvement, the latter understood as a profound change in the construction of government actions that privilege health care over disease care.

The sense of risk that now crosses us, gives way to attitudes that, on the one hand, can be justified from different directions, but that also awaken and generate in our immediate environment behaviors that can become disproportionate to the threat posed by the virus. It represents, in such a way that we go to the care of our health, of our body, from a compulsive concept of care and procurement that, in other new routes, will end up making us sick: health that makes us sick [50]. The compulsive purchase of cleaning products, including toilet paper, the terror of sneezing and the proximity of people, not only on the street but in our most immediate circles, the systematic and recommended hand washing throughout the day, from which psychologically speaking it will not be easy to get rid of; these are just some references to our new behaviors associated with the environment of fear and risk that have been integrated into a particular idea of safeguarding our health. The so-called emotional health is today more than ever in question; to the concerns and problems recognized before the pandemic, there are now a host of new horizons and routes through which the need for support to face the fears derived from the disease, the loneliness of confinement, the increase in work stress (linked now to the home office), uncertainties about the future, among the most important.

Among the large amount of information and "specialized" statements on the subject, it is said that the COVID-19 that we suffer today represents just the beginning of a set of problems that announce the presence of future viruses, which in the short term, given our predominant forms of consumption and interaction/predation of nature, they will be present for years to come. Something for which we are not prepared, given the predominance of an evolutionary and developmental ideology typical of modernity [51], which made us believe, still in the second half of the last century that the alleged scientific and technological development would liberate us once and for all of the suffering caused by diseases, we forgot that all life is in permanent transformation [52]; the first generation of penicillin has nothing to do with the last generation penicillins, but we also tend to ignore that the effectiveness of the last generation drugs brings harmful side effects. We should keep in mind the idea and the sense that disease is an inherent part of our human condition: the relationship and coexistence with our environment, invariably has consequences in the homeostasis of our bodies, and of the so-called social body; which means that both disease and death are intrinsic conditions to our historical social condition, to our human condition; they have accompanied us from the beginning of our history and will be present in their different and diverse expressions and interpretations in each of the reference historical and cultural contexts, always as part of the balances of economic, political, religious power, etc. [53, 54].

In the scenario of a global economy and a culture of consumption, new advertising strategies are put in place that overshadow and dilute any idea that goes in the direction of reformulating the socio-economic and political model, which could be considered as a positive lesson from COVID-19, and this is not necessarily related to the end of capitalism as some might intuit; what a sector of the population does is ask itself when can we go shopping? When can we travel and go on vacation? It is a sector of the population whose purchasing power allows it to ask these types of questions, which give account of the way in which marketing undermines, permeates, negotiates with our daily lives [55]. Of course, for the vast majority, the outlook is bleak and full of uncertainty due to the loss of employment or the bankruptcy of small and medium-sized companies.

On the other hand, the incorporation of the mask into our daily work, expands its penetration in the different strata of the population, and has gone from being a pharmaceutical product to being a fashion product, to which designs and materials associated with commercial firms are incorporated in the world of fashion, without deeply questioning the implications of the use of an artifact that should not be assumed naturally as part of our daily lives, and indefinitely. Under the protection of the pandemic, a business line that grows and thrives with the disease arises and is strengthened, which is assumed as normal, natural and even necessary, when in reality, it should be a possibility, an access way to rethink health and its profound political and economic implications, its consequences at the level of social relationships and interactions both at the macro-institutional level and at the level of a recognized daily life will never be the same as before the pandemic. Hence, the increasingly widespread and accepted use of the call: new normal.

These situations that go through our lives today are actually the starting point, the announcement of profound changes in the field of subjectivities, where the most elementary processes that give meaning and meaning to 
everyday relationships and interactions are configured and regulated life in society [56-58]. Fear of contact, and of physical proximity, not only modifies our day-to-day interactions, but in the macro-economic and social field, it will come to signify different forms of consumption of goods and services. The different areas of the economy are already preparing for what has been called the new normal: restaurants, cinemas, bars, concerts, museums, parks, public transport, air travel, the street itself in its most basic sense. and generic, they are called to provide for the consumption of their goods and services the incorporation of the most varied types of barriers that separate consumers, travelers, pedestrians and citizens; this separation goes beyond the mere anecdotal enunciation, but rather changes the meaning and meaning of coexistence and social interaction, already marked in this century by the profound upheaval of life, as a result of the appearance and predominance of the virtual reality, the internet, the ubiquitous social networks.

Likewise, and no less important, point out an issue that in the short term will give rise to an infinity of reflections and reformulations in the field of social sciences, and that has to do with the function and attributions of the contemporary state. Coinciding with Agamben in his most recent statements, and on the occasion of the outbreak of the pandemic by COVID-19, the state of exception is confirmed as the new model of social political regulation, where social subjects (citizens say political science), accept (and in many worrying cases they demand) the abrupt and dangerous curtailment of their freedoms and rights, for the sake of security and invoking the intended collective benefit [59]. It is enough to recover the experience of European countries, where this state of exception has taken place, imposing punishments, fines, organizing reviews, limits to mobility in the streets and public roads to, in the interests of security, assert the power of the State, their legitimate use of force (monopoly of violence), to safeguard the safety of citizens. Something that Michael Foucault refers to in terms of the consideration of life by power [60]. In the global world, the rejection of the vaccine by different groups of the population can be read as resistance to a complex process of medicalization that has been strengthened in recent decades, and that goes back to the way in which since the 18th century, both conduct and behavior, the human body and existence itself, are traversed by a complex process in which the development of medicine, its propagation and social presence has been increasingly present in the different areas of life in society. In this sense, the vein of research on the relationship between health and subjectivity, which the pandemic has given way, must be collected and addressed from a wide spectrum of interpretation and knowledge with a view to the viability of interventions that strengthen follow-up and the control of what the mosaic of health represents, as we live it today in the case of the pandemic; although it must be said that it is not in any sense a new phenomenon, since the need and importance of an approach to health from its subjective edges has been gaining strength in the field of health sociology, what happens is that due to its dimensions, implications and complexity, the pandemic makes it more relevant and evident today, in the context of the controversial relationship between the state and civil society.

At the beginning of the present XXI century, in the face of the attack on the twin towers, and under the pretext of security, rights and freedoms are cut and restricted: at airports, in the face of "exhaustive" reviews (a clear attack on human rights). Humans, began to say "it is for your safety" and in the face of this alleged argument it has been impossible to reverse a series of measures that in another of its more current expressions has to do with p. For example, with the omnipresent installation of cameras in all spaces of relationship and social coexistence, not only in the streets, in offices, in any workplace, but in our own homes, all for security reasons [61]. This is another very important field of reflection that leaves us pending the global situation in which we participate today.

\section{Public health management}

Finally, it is in this sense that the knowledge of a phenomenon, that of the health problem, becomes important for the different government instances, which in addition to its medical condition, permanently refers to its historical, economic, social, political character and condition and cultural. Let us bear in mind that traditionally, health has been considered as a source of power and social legitimation. Thus, over time, public policies represent the mechanism, the instrument from which governments manage the demands of the population, attending to their demands and needs [62]. Today, the concept of governance seems to try to overcome a series of issues that in the recent past limited and even hindered communication between governments and civil society, the pretense of moving towards a more balanced interrelation between governments, society civil society and markets, in the interest of a more balanced development, represents a very important step in terms of modifying and updating the ways in which until very recently it has been working, specifically in the field of health. The active participation of the population is undoubtedly required to achieve important changes that involve the commitment of the different social sectors without which it is impossible to achieve significant changes in health care and attention [63]. The 
phenomenon that we are currently experiencing at the global level represents a clear example that without the participation of all it will be impossible to achieve favorable results for the management and control of the pandemic. The government has a leading role in the management of processes, whether medical or regulatory, for the implementation of tools and instruments that can better contribute to managing the health crisis and its economic and social implications. The population has a prominent role based on individual and collective participation, in such a way that in the diversity of political and ideological positions, they can recognize and measure their historical role. In its condition of social practice [64], the public administration is responsible for conciliating and negotiating what best corresponds to the interests and needs of its different groups and communities, beyond the predominance of large economic and financial interests, from among those that highlight the powerful medical and pharmaceutical industry.

Health phenomena transcend the field of medicine, and place us as we experience it today, at an unprecedented crossroads, but where it is clearly noticed, that in which this short text strives to show: the health process, disease, death, is first of all a phenomenon of a social nature, and it must be treated in this way from government instances, thus guaranteeing its best management and approach in the broadest and most critical terms of governance.

\section{Conclusion}

The pandemic we are experiencing today represents a turning point in world history. It is a phenomenon that in some sense continues to be undervalued from the governmental and social spheres. The impact on the economy and society, taking into account their most heartfelt expressions and representations in everyday life, are just the tip of the iceberg of a series of phenomena that, in the short and medium term, as recounted in this document Based on statements made by international organizations such as WHO and PAHO, as well as those recognized voices in the international social and medical sphere, they will be part of our future in the short and medium term. It is presumed that the COVID-19 pandemic represents just the beginning of a new stage in the history of the world, in which with increasing frequency the irruption of contagious infectious diseases unknown until now will be suffered. It is understood that the health crisis we are going through will generate a certain knowledge for the management of future ailments, implementing new forms of care and monitoring of the disease, as well as a series of mechanisms and recommendations in the ways in which we have socially interacted up to now: confirmation of emerging forms of work and its regulation, new expressions of family and community coexistence, new educational mechanisms and strategies, innovative proposals for travel and tourism etc; however, and perhaps with greater urgency and importance, it is essential to rethink the origin of this type of phenomenon, recognizing the causes and conditioning factors that conceal large economic interests related not only to the clear and persistent social inequalities at the global level, but also to the forms of the relationship that in this period of history we maintain with an environmental environment that, despite the alarm signals referred to by the so-called climate change, for example, does not seem to find an answer and is ignored by governments and their societies. It is not about being alarmists, but about working in favor of a kind of conscience regarding the finiteness of the planet and its natural resources that, after all, represent the basis and sustenance of our survival, and also the curtain of background of future ailments.

\section{References}

[1] Dubet, F. (2006). The multiplied inequalities. Editorial UAEMex.

[2] Goffman, E. (2003). Stigma. The deteriorated identity. Editorial Amorrortu.

[3] Donati, P. (1994). Health Sociology Manual. Editorial Díaz de Santos.

[4] Ackerknecht, E. (1985). Medicine and social anthropology. Editorial. Akal University.

[5] Donati, P. (1994). Health Sociology Manual. Editorial Díaz de Santos.

[6] Rosen, G. (1985). From the Medical Police to Social Medicine. Editorial Siglo XXI.

[7] Hernández, C., Maricelys, M., Pérez, M., García, V. (2012). “Philosophy, the health-disease process and the environment.” Habanera Magazine of Medical Sciences, 11(Suppl. 5), 727-735.

[8] Garrett, L. (1995). The Coming Plague. Newly emerging diseases in a world out of balance, New York, Farrar, Straus and Giroux, 1995, p. 769.

[9] Donati, P. (1994). Health Sociology Manual. Editorial Díaz de Santos.

[10] Mckeown, T. and Lowe, C. (1989). Introduction to social medicine. Editorial Siglo XXI Editores. 
[11] Ackerknecht, E. (1985). Medicine and social anthropology. Editorial. Akal University.

[12] González, N. (2018). "Medicalization of death. Elements of discussion and analysis for a critical approach from the social sciences”. Cultural Magazine, Vol. 6, pp. 1-27.

[13] Bauman, Z. (2013). Culture in the world of liquid modernity. Editorial Fondo de Cultura Económica.

[14] Castel, R. (2010). The rise of uncertainties. Work, protections, status of the individual. Editorial Fondo de Cultura Económica.

[15] WHO (World Health Organization). (2021). hat is a pandemic? https://www.who.int/csr/disease/swineflu/frequently_ asked_questions/pandemic/es/. Accessed June 2, 2021.

[16] Laplatine, F. (1999). Anthropology of the disease. Editions of the Sun.

[17] Mckeown, T. and Lowe, C. (1989). Introduction to social medicine. Editorial Siglo XXI Editores.

[18] Breilh, J. (1988). Epidemiology, Economics, Medicine and Politics. Editorial Fontamara.

[19] Rosen, G. (1985). From the Medical Police to Social Medicine. Editorial Siglo XXI.

[20] MacMahon, B. and Pugh, F. (1984). Principles and methods of epidemiology. Editorial la Prensa Mexicana.

[21] Dubet, F. (2006). The multiplied inequalities. Editorial UAEMex.

[22] Farmer, Paul. (2000). “Social inequalities and infectious diseases”. Journal of Population Papers, No. 23, January-March, pp. 181-201. CIEAP/UAEMEX.

[23] Hernández, C., Maricelys, M., Pérez, M., and García, V. (2012). "Philosophy, the health-disease process and the environment.” Habanera Magazine of Medical Sciences, 11(Suppl. 5), 727-735.

[24] McKeown, T. (1990). The origins of human disease. Critical Editorial.

[25] MacMahon, B. and Pugh, F. (1984). Principles and methods of epidemiology. Editorial la Prensa Mexicana.

[26] Horton, Richard. (2020). “COVID-19 is not a pandemic” Volume 396, Issue 10255. Published: September 26, 2020. DOI: https: //doi.org/10.1016/S0140-6736 (20) 32000-6. The Lancet. UK.

[27] Horton, Richard. (2020). “COVID-19 is not a pandemic”. Volume 396, Issue 10255. Published: September 26, 2020. DOI: https: //doi.org/10.1016/S0140-6736 (20) 32000-6.The Lancet. UK.

[28] WHO (World Health Organization). (2020) Social determinants of health. https://www.who.int/social_determinants/es/. Accessed June 15, 2020.

[29] El País. (2020). Is it possible to solve the problems of a pandemic without having the social sciences? Rooms, Javier. October $14,2020$.

[30] La Jornada. (2020). “Intellectuals on the coronavirus”. Olea, Flores Victor. March 30, 2020.

[31] Agamben, G., Slavoj Z., et al. (2020). Soup of Wuhan, Buenos Aires: ASPO (Preventive and Obligatory Social Isolation. Https://repositorio.uca.edu.ar/handle/123456789/10038.

[32] Boaventura, De S. (2020). The cruel pedagogy of the virus. Editorial CLACSO.

[33] Franco, Á. (2001). “The globalization of health: between economic reductionism and citizen solidarity (second part)”. Journal of the National School of Public Health. July-December, year/vol. 20, number 002. Universidad de Antioquia, Colombia, 2001, pp. 103-118.

[34] Rosen, G. (1985). From the Medical Police to Social Medicine. Editorial Siglo XXI.

[35] WHO (World Health Organization). (2020). Social determinants of health. https://www.who.int/social_determinants/es/. Accessed June 15, 2020.

[36] WHO (World Health Organization). (2020). Social determinants of health. https://www.who.int/social_determinants/es/. Accessed June 15, 2020.

[37] Garrett, L. (1996). The return of infectious diseases. En Foreign Affairs, year 1996, January-February, pp. 193-208.

[38] Political Expansion. (2020). "Iztapalapa and Gustavo A. Madero are the mayoralties with the most infections and the most deaths.” https://politica.expansion.mx/cdmx/2020/04/21/iztapalapa-y-gustavo-a-madero-son-las-alcaldias-con-mas-contagiosy-mas-muertes. Accessed May 29, 2020.

[39] PUED (University Program for Development Studies). (2021). Estimates of extreme poverty and poverty, both by income in Mexico, between April and the IV quarter of 2020; period of full development of the pandemic. UNAM.

[40] CONEVAL (National Council for the Evaluation of Social Development Policy). (2021). Social policy in the context of the SARS-CoV-2 (Covid-19) virus pandemic in Mexico. Published by CONEVAL/México.

[41] PUED (University Program for Development Studies). (2021). Estimates of extreme poverty and poverty, both by income in Mexico, between April and the IV quarter of 2020; period of full development of the pandemic. UNAM. 
[42] PAHO. (2020). Declaration of Alma Ata. The Pan American Health Organization. Promoting health in the Americas. PAHO.https: //www.paho.org/hq/dmdocuments/2012/Alma-Ata- 1978 Declaration. Retrieved May 29, 2020.

[43] WHO (World Health Organization). (2020). Return to Alma Ata. https://www.who.int/dg/20080915/es/. Accessed June 15, 2020.

[44] UNDP. (United Nations Development Program). (2020). Millennium Development Goals. https://www.undp.org/content/ undp/es/home/sdgoverview/mdg_goals.html. Retrieved June 15, 2020.

[45] WHO (World Health Organization). (2020). Millennium Development Goals. https://www.who.int/topics/millennium_ development_goals/about/es/. Accessed May 29, 2020.

[46] González, N. (Coord.) (2007). Poverty and health in the State of Mexico: Non-hospital diabetes care. Editorial Miguel Ángel Porrúa.

[47] Zizek, S. (2020). Pandemic. Covid-19 shakes the world. Editorial New ANAGRAMA notebooks.

[48] Goffman, E. (2003). Stigma. The deteriorated identity. Editorial Amorrortu.

[49] Hernández, Rodríguez José. (2021). “Impact of COVID-19 on people's mental health.” Medicentro Electrónica, 24(3), 578-594. http://scielo.sld.cu/scielo.php?script=sci_arttext\&pid=S1029-30432020000300578\&lng=es\&tlng=es.

[50] Passos, R. (2008). Health that does bad. A study around the thought of IvanIllich. Editorial Place editorial.

[51] Vattimo, G. (1994). About postmodernism. Editorial Anthropos.

[52] Garrett, L. (1996). The return of infectious diseases. En Foreign Affairs, 1996, January-February, pp. 193-208.

[53] Mora, F. and Hersch, P. (1990). Introduction to social medicine and public health. Editorial Trillas.

[54] McKeown, T. (1990). The origins of human disease. Critical Editorial.

[55] Sassatelli, R. (2012). Consumption, culture and society. Editorial Amorrortu.

[56] Illouz, Eva. (2007). Frozen intimacies. Emotions in capitalism. Editorial Katz.

[57] Morris, D. (1996). The culture of pain. Editorial Andrés Bello.

[58] Wolf, M. (1988). Sociologies of everyday life. Editorial CATEDRA.

[59] Agamben, G., Slavoj, Z., et al. (2020). Soup of Wuhan, Buenos Aires: ASPO (Preventive and Obligatory Social Isolation. Https://repositorio.uca.edu.ar/handle/123456789/10038.

[60] Foucault, M. (2001). Defend society. Editorial Fondo de Cultura Económica.

[61] Mattelart, A. (2009). A guarded world. Editorial Paidós.

[62] Tapia-Cruz, J. (2006). "Objectives of the health system in Mexico: importance for the population and its determinants". Public Health of Mexico, Vol. 48, No. 2, March-April, pp. 113-126.

[63] Aguilar, L. (2006). Governance and public management. Editorial Fondo de Cultura Económica.

[64] Ibarra, E. (1998). “Administration and organization at the end of the millennium: rationalism, irrationalism and governmentality.” In: Ramírez, Grajeda Beatriz (Coord.) The role of the administrator in the current context. Editorial UAM-Azcapotzalco. 